\title{
Keeping Talents in the Transport and Logistics Enterprises: Case Study from the Czech Republic
}

\section{Lenka Ližbetinová ${ }^{1}$, Eva Nedeliaková $^{2}$, Radovan Soušek ${ }^{3}$, Michal Greguš ${ }^{4}$}

${ }^{1}$ Institute of Technology and Business, Okružní 517/10, 37001 České Budějovice, Czech Republic, lizbetinova@mail.vstecb.cz

${ }^{2}$ Faculty of Operation and Economics of Transport, University of Zilina, Univerzitná 8215/1, 01026 Žilina, Slovakia, eva.nedeliakova@fpedas.uniza.sk

${ }^{3}$ Faculty of Eonomics, University od Pardubice, Studentská 95, 53210 Pardubice

2, Czech Republic, radovan.sousek@upce.cz

${ }^{4}$ Department of Information Systems, Faculty of Management, Comenius University in Bratislava, Odbojárov 10, 82005 Bratislava, Slovak Republic; michal.gregus@fm.uniba.sk

\footnotetext{
Abstract: The aim of the article is to identify the motivation preferences of Czech managers on critical management positions of transport and logistics enterprises and to determine the method for the effective setting of the motivation factors in the interest of keeping them in an enterprise. The article is based on research outcomes from transport and logistics enterprises where the focus is on managers identified as talents by the enterprises. Research was conducted in 2018 in the Czech Republic using a questionnaire. In research, 154 managers were interviewed. Data were processed using basic descriptive statistics. The proposed effective setting of motivational elements is based on the use of a method for determining an appropriate variant - AHP multicriteria decision making method. The results of the article can serve to help entrepreneurs not only in the field of transport and logistics services. Other enterprises also have the potential to gain a strong system not only to retain their talents in society, but also to create satisfaction and commitment to the enterprises. The presented way of setting motivation factors is universally applicable to any sector and regional location.
} 


\section{Introduction}

Current labour market is changing along with business environment in a very high pace. Companies own significant amount of intangible assets, i.e. human resources, high-quality and qualified labour force, whose value may be improved further [1] [2]. Such perspective employees have the potential to help enterprises in overcoming hard economic times and affect economic growth in a positive way [3]. Considering the actual situation in labour market, it's becoming more demanding for companies and entrepreneurs to hire, educate and keep the talents [4] [5]. For the companies to keep such employees, they are forced to create attractive work environment [6] [7] [8]. Companies are aware of the fact how important it is to have talented employees. Such talent means an individual with high potential - his/her own combination of certain extraordinary capacities and personal properties that distinguish him, also bringing added value to the company [9]. In the corporate practice, talent is considered as an ability to achieve performance above standard as the performance is the aspect such company requires, measures and appreciates [10]. Talents are educated, in particular, for critical management positions, having significant impact on company performance as a whole. To get and educate a talent, it requires significant effort from the company as well as time and costs. Their loss and even shift to competitors may weaken the company markedly [11]. Therefore, talent management area grows in importance within a wider spectrum of organisations and it's becoming a key challenge in the human resources area companies face in different industries [12] [13] [14]. This trend is fueled by the incoming $4^{\text {th }}$ industrial revolution, when the paradigm of human resources management is changing [15]. Coming new technologies and concepts such as automation, creation of a global cybernetic space (GCS) [16], process digitalisation, system integration, autonomous robotics and vehicles, digitalisation or systems of artificial intelligence modify the already implemented procedures and mindset in companies, in particular in the area of industrial production [17] [18] [19]. Also, the demands on human resources are changing markedly. Although the estimates count on a decrease of demands on the volume of human resources, companies will be facing the need of change to their structure of employees by the implementation of more intelligent systems automation. According to Dočkalová [20], development of technologies may lead to a mass unemployment. On the basis of its research, the German Ministry of Industry and Development stated that the changes to structure of labour positions brought more than $10 \%$ increase in work positions in operation companies as a consequence of automation [21]. Subsequently, by an increase in the volume of production, completely new work positions were created, but a high demand for highly qualified IT employees, able to control and program software for majority of machines [21], as well. Research of the Czech Ministry points to a decrease in work positions by one third and to an increase of new positions by one eight [22]. 
On the other hand, specific need is being created for higher management that will be able to react on the shift process within implementation of elements and system changes in the industry flexibly 4.0 [15] [23]. Subsequently, they will be able to control the processes and change their current management mindset in accordance with the modification of management paradigm [24]. This requirement will have the highest importance for managers at key (or critical) management positions, ideal for the so-called talents in this case. Within the context of industrial revolution 4.0, talent may be flexibly adjusted to the requirements for implementation of technological elements in enterprise and has necessary competences for the management of intelligent systems, new procedures as well as human resources [25]. Critical positions (designated also as key positions) are such positions that are decisive for the achievement of success in organisation. Non-timely occupation of such positions may lead to a serious disruption to enterprise functioning [10] [25]. Therefore, it's necessary to reveal and define key positions and to plan the employees for these positions sufficiently in advance so unexpected complications are thus avoided. Key positions may be identified from the analysis of organisational structure. These are, in particular, strategic positions of higher management [8].

\subsection{Keeping Talents in Enterprise}

Implementation of elements of the industry 4.0 is considered risky by enterprises in the $\mathrm{CR}$, in particular due to the insufficiency of successful exemplary business cases. The problems are the shortcomings of studies for the integration of elements for industry 4.0 for top management and insufficient confidence in new procedures [26]. This is a hard task and this process could be critical without highquality workers of the "talent pool." Creation of appropriate conditions for talents at key positions represents a reduction or the risk of their loss and potential improvement of loyalty towards respective enterprise [27]. According to Grenčíková et al. [28], number of experts are focusing mainly on the identification of talent pool in organisation, on their planning and development. However, their motivation and keeping them is also an important element [25] [29] [30].

The trends stated above are related also to the area of transportation and logistics within the Central Europe [24]. Transportation enterprises struggle with shortage of qualified and high-quality human resources. Significant shortage of necessary human resources are often solved by the employed of riskier groups of workers graduates and older applicants. An important source are foreign workers from Ukraine, Russia, Mongolia and other countries [31] [32]. Another and also an innovative solution at the same time is the implementation of automation and smart systems into respective procedures, where it's possible to substitute human resources. A huge problem is to find and keep high-quality qualified and talented workers for the positions of higher management. Here, it's appropriate to use a targeted motivation system increasing the satisfaction of this group of workers, 
and according to Jigjiddorj et al. [27], it will also provide loyalty towards enterprise secondarily. Hitka [33] states that a targeted motivation program for specific categories of workers has a higher efficiency and it's financially and timely more effective. This statement is also supported by the fact that if the applied motivational element is strongly preferred by workers, it's more effective than the combination of other elements that may be financially or timely more demanding. An appropriate choice and application of motivational program, with regard to the preferences of certain group of workers, creates opportunities for number of companies to develop a long-term competitive advantage [34] and for the security of competitiveness in global environment. This article follows the studies focused on motivation of workers and supplements the knowledge by a specific group of workers, representing a key element of success not only in the area of transportation and logistics. Presented results enrich the knowledge base by practical application within a case study from transportation and logistics environment of the Czech Republic.

\section{Methodology}

The objective of this article is to identify the motivation preferences of Czech managers at critical management positions (identified as talents by the enterprises) of transportation and logistic enterprises, and the determination of method for effective setup of effects of motivation factors for the purpose of keeping them in such enterprise. This article is based on the outcomes of research within enterprises active in the transportation and logistics industry where the attention is paid to managers at critical positions. Research was held in 2018 in the Czech Republic through a questionnaire. Within the research, 154 managers were interviewed, such enterprises marked as key high-quality employees at critical positions or planned for these positions in the enterprise, so-called talents (these are selected workers of middle and top management). 32 enterprises were engaged in this research. Characteristics of research sample was presented in the Table 1.

Table 1

Characteristic of research sample

\begin{tabular}{|c|c|c|c|c|c|c|c|c|}
\hline & \multicolumn{4}{|c|}{ Gender } & \multicolumn{2}{|c|}{ Total } \\
\hline & & & Women & $\%$ & Men & $\%$ & Count & $\%$ \\
\hline \multirow{8}{*}{$\underset{\&}{8}$} & \multirow{2}{*}{ Up to 30 years } & Count & 15 & $42.9 \%$ & 20 & $57.1 \%$ & 35 & $100.0 \%$ \\
\hline & & $\%$ within Gender & $20.3 \%$ & & $25.0 \%$ & & $22.7 \%$ & \\
\hline & \multirow{2}{*}{$\begin{array}{l}31-40 \\
\text { years }\end{array}$} & Count & 18 & $37.5 \%$ & 30 & $62.5 \%$ & 48 & $100.0 \%$ \\
\hline & & $\%$ within Gender & $24.3 \%$ & & $37.5 \%$ & & $31.2 \%$ & \\
\hline & \multirow{2}{*}{$41-50$ years } & Count & 27 & $54.0 \%$ & 23 & $46.0 \%$ & 50 & $100.0 \%$ \\
\hline & & $\%$ within Gender & $36.5 \%$ & & $28.8 \%$ & & $32.5 \%$ & \\
\hline & \multirow{2}{*}{51 and above } & Count & 14 & $66.7 \%$ & 7 & $33.3 \%$ & 21 & $100.0 \%$ \\
\hline & & $\%$ within Gender & $18.9 \%$ & & $8.8 \%$ & & $13.6 \%$ & \\
\hline 5 & Less than a 1 & Count & 8 & $53.3 \%$ & 7 & $46.7 \%$ & 15 & $100.0 \%$ \\
\hline
\end{tabular}




\begin{tabular}{|c|c|c|c|c|c|c|c|c|}
\hline year & $\%$ within Gender & $10.8 \%$ & & $8.8 \%$ & & $9.7 \%$ & \\
\cline { 2 - 8 } $\begin{array}{c}\text { from 1 year to } \\
3 \text { years }\end{array}$ & Count & 12 & $42.9 \%$ & 16 & $57.1 \%$ & 28 & $100.0 \%$ \\
\cline { 2 - 8 } & $\%$ within Gender & $16.2 \%$ & & $20.0 \%$ & & $18.2 \%$ & \\
\hline $\begin{array}{c}\text { from 4 years to } \\
6 \text { years }\end{array}$ & Count & 11 & $35.5 \%$ & 20 & $64.5 \%$ & 31 & $100.0 \%$ \\
\cline { 2 - 8 } & $\%$ within Gender & $14.9 \%$ & & $25.0 \%$ & & $20.1 \%$ & \\
\hline $\begin{array}{c}\text { from 7 years to } \\
9 \text { years }\end{array}$ & Count & 11 & $42.3 \%$ & 15 & $57.7 \%$ & 26 & $100.0 \%$ \\
\cline { 2 - 8 } & $\%$ within Gender & $14.9 \%$ & & $18.8 \%$ & & $16.9 \%$ & \\
\hline $\begin{array}{c}10 \text { years and } \\
\text { above }\end{array}$ & Count & 32 & $59.3 \%$ & 22 & $40.7 \%$ & 54 & $100.0 \%$ \\
\hline Total & Count & 74 & $48.1 \%$ & 80 & $51.9 \%$ & 154 & $100.0 \%$ \\
\hline
\end{tabular}

The portion of men and women in the sample is relatively balanced, while in case of women, higher age categories prevail as well as their period of practice in comparison to men. This is probably caused by the fact that the Czech Republic belongs to masculine culture [35], preferring men for leading positions, in particular within top management. It takes more time to women to get to such positions [36] [37]. This questionnaire consisted of two basic parts - fundamental data about respondents (age, assignment, region in the Czech Republic, period of practice) and part for the evaluation of important of motivation factors. Respondents could evaluate 30 motivation factors on the basis of their subjective opinion on the importance at the Likert scale form 1 to 5 (1- unimportant to 5 the most important). Data were processed by the use of basic descriptive statistics and the verification of their significant differences was performed by the ANOVA test.

Suggested effective setting of motivation elements is based on the use of multicriteria method of evaluation of options. Within the nature of input data and decision task, it's possible to use different methods of multi-criteria decisionmaking, e.g. the Decision matrix method, weighted sum approach method, TOPSIS or AHP method. The Decision matrix method [38] is a relatively simple and fast method of choosing the right option. With this method, options for each criterium within the range of 1-10 are evaluated, where 1 means inappropriate and 10 ideal). Following multiplication of this evaluation by the use of weight of criterium importance will determine the most optimal option. An analogical method is the weighted sum approach method, evaluating options according to their benefit within criteria from 0 to 1 , when 0 means no benefit and 1 means maximum benefit [37]. The TOPSIS method works with an ideal and basal value of option and with a calculation of distance of options from these values. This method is more accurate than the weighted sum approach method and eliminates its defficiencies. The AHP multicriteria decision making method, based on a pair comparison of option appropriateness according to respective criteria, is more comprehensive and unbiased [39] [40]. Also, the use of pair verbal evaluation allows an easier decision and the requirements for consistency of the Sattyho matrix ensure more accurate setting of pair comparison of options. Its disadvantage is based on a relatively high time demanding nature in case there are more criteria and options used. In this article, selection of appropriate option will be solved by the use of the AHP method, while the hierarchy of decision-making 
task is illustrated on Figure 1, where $\mathrm{K} 1-10$ is the criterium in a form of motivation factor and V1-3 is the evaluated option. Weights of criteria (motivation factors) are recalculated on the basis of results of the preferences' research of respondents according to gender. Within the solution of decision-making task, 10 most important criteria are considered for a group of men and separately for a group of women. This task application is solved in an environment of specific transport enterprise that submitted three options of motivation programs. The appropriateness of respective options according to each criterium is evaluated by three expert evaluators, consisting of top management workers and human resources department of the enterprise.

Figure 1

Hierarchy of solved task by AHP

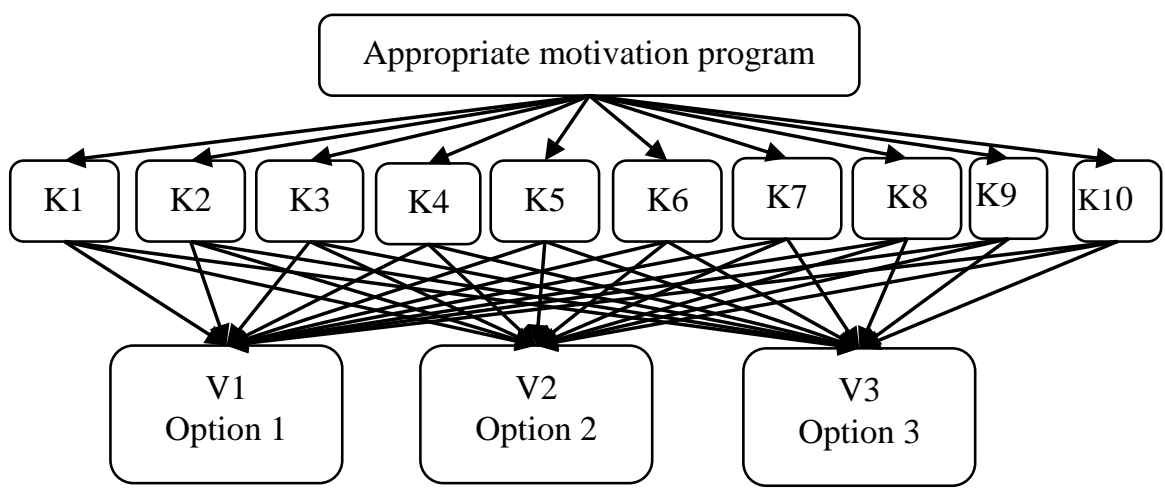

In accordance with the principle of the AHP method, evaluators assign the weight of appropriateness of option in the range of 1 to 9 (1- both options take part on objective intervention in the same portion, 3 - first option is more appropriate than the second option to certain extent, 5 - first option is significantly more important than the second one, 7 - first option is far more important than the second one, and 9 - absolute preference of first option against the second one according to certain criterium). If the first option is less important than the other, this relationship is expressed by the inverse of the scales (1/1-9). This evaluation is expressed in formula 1 , where " $k$ " represents the number of all options and " $p$ " means the evaluation on the range of importance for respective option. Consequently, as the assigned value i-th criterion is marked as pi, it is possible to estimate scales (Eq. 1) by calculation [38]. Consequently, the final evaluation can be entered in Saaty's matrix, where each element Sij (Eq. 2 - 4) can be obtained as the ratio of estimating of weights for the $\mathrm{i}$-th and $\mathrm{j}$-th option [41]:

$$
v_{i}=\frac{p_{i}}{\sum_{i=1}^{k} p_{i}} i=1,2, \ldots, k(1)
$$

$$
\mathrm{s}_{\mathrm{i}} \approx \frac{\mathrm{v}_{\mathrm{i}}}{\mathrm{v}_{\mathrm{j}}}(i, j=1,2,3, \ldots k)
$$




$$
v_{i}=\left(\prod_{j=1}^{k} s_{i j}\right)^{1 / k} i=1,2, \ldots ., k(3) \quad v_{i}=\frac{v_{i}^{\prime}}{\sum_{i=1}^{k} v_{i}^{\prime}} i=1,2, \ldots, k(4)
$$

Substitution of calculated elements [42] of matrix into the Eq. 3 and 4 allows the calculation of weights of appropriateness of each option. Saaty's method is the most appropriate form of determination [43] of options' appropriateness for the purpose of identification of appropriate motivation program in our case study for transport enterprise, as it respects comprehensive relations between respective criteria and alternative options. Within the research, following work hypotheses were set:

H1 From the perspective of gender of workers, marked as talents by transport enterprises (working in middle or top management), the evaluation of importance of motivation factors has no statistically important differences.

H2 The most appropriate option for workers marked as talents in transport enterprises, is the motivation program with the highest level of base wage.

\section{Results and Discussion}

Acquired data from the research were processed by the use of basic descriptive statistics, whose results are presented in the Table 2. Average evaluation of preferences of respective motivation factors states the arithmetic mean value. Within the results, it is diversified into the groups of women and men. Standard error of mean value lies within the range from 0.077 to 0.138 , confirming the interpretability of calculated mean values. Following the results of average evaluation of importance of motivation factors (Table 2), the most important factor at workplace for key workers in top management, considered as talents according to their employer, is the atmosphere in workplace for both groups men (arithmetic mean value 2.29) and women (4.58). Subsequently, preferences of men and women differ. Men consider the base wage (2.25) as the second most important factor while women placed it to the $5^{\text {th }}$ place in importance (4.43). For women, a factor of the same importance as the atmosphere at workplace, are good colleagues (4.58), seen by men only at the third place of importance (4.20). As the third most important factor, seen by women, is the approach of superior employee (4.54). The fourth, most important factor, is identical for both gender categories, and that's the communication at workplace (4.51 for women and 4.19 for men) and also the application of their own skills (4.41 for women and 4.16 for men). Subsequently, women see fair evaluation as important (4.39), subject and type of work activities (4.35), work environment (4.35) and safety at workplace (4.27). In case of men, they assign then the highest importance to the subject (4.15) and type of performed work, certainty of such workplace (4.14), work environment (4.10) 
and education and personal growth (4.06). On the basis of results of questionnaire, it may be stated that, from the gender point of view, the highest importance is not assigned to the motivation factor in a form of base salary.

Table 2

Basic statistical characteristics of the importance of motivational factors

\begin{tabular}{|c|c|c|c|c|c|c|c|c|c|c|}
\hline \multirow[b]{2}{*}{ 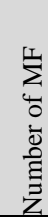 } & \multirow[t]{2}{*}{ Motivational factor (MF) } & \multicolumn{4}{|c|}{ Women } & \multicolumn{4}{|c|}{ Men } & \multirow[b]{2}{*}{ 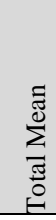 } \\
\hline & & $\stackrel{\Xi}{\Xi}$ & 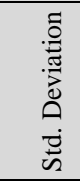 & 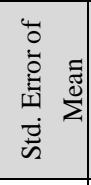 & 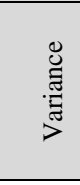 & $\underset{\Xi}{\stackrel{\Xi}{\Sigma}}$ & 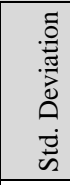 & 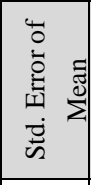 & 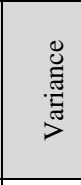 & \\
\hline 1 & Workplace atmosphere & 4.58 & 0.844 & 0.098 & 0.713 & 4.29 & 1.105 & 0.123 & 1.220 & 4.43 \\
\hline 2 & g team & 4.58 & 0.794 & 0.092 & 0.630 & 4.20 & 0.947 & 0.106 & 0.896 & 4.38 \\
\hline 3 & More financial $r$ & 4.09 & 0.953 & 0.111 & 0.909 & 3.98 & 1.102 & 0.123 & 1.215 & 4.03 \\
\hline 4 & Physical demands of work & 3.45 & 0.953 & 0.111 & 0.908 & 3.38 & 1.084 & 0.121 & 1.174 & 3.41 \\
\hline 5 & Job & 4.26 & 0.908 & 0.105 & 0.824 & 4.14 & 1.064 & 0.119 & 1.133 & 4.19 \\
\hline 6 & Comm & 4.51 & 0.832 & 0.097 & 0.692 & 4.19 & 0.901 & 0.101 & 0.813 & 4.34 \\
\hline 7 & Prestige / company name & 4.03 & 0.936 & 0.109 & 0.876 & 3.65 & 1.104 & 0.123 & 1.218 & 3.83 \\
\hline 8 & Applying own abilities & 4.41 & 0.739 & 0.086 & 0.546 & 4.16 & 0.920 & 0.103 & 0.847 & 4.28 \\
\hline 9 & The content and type of work & 4.35 & 0.801 & 0.093 & 0.642 & 4.15 & 0.901 & 0.101 & 0.813 & 4.25 \\
\hline 10 & Performance feedback & 4.24 & 0.791 & 0.092 & 0.625 & 3.98 & 0.886 & 0.099 & 0.784 & 4.10 \\
\hline 11 & g hours & 4.24 & 1.018 & 0.118 & 1.036 & 4.04 & 0.974 & 0.109 & 0.948 & 4.14 \\
\hline 12 & Working environment & 5 & 0.784 & 91 & 615 & .10 & 0.949 & 0.106 & 0.901 & 4.22 \\
\hline 13 & Work perfo & 4.26 & 0.795 & 0.092 & 0.632 & 4.00 & 0.842 & 0.094 & 0.709 & 4.12 \\
\hline 14 & Career advanc & 4.15 & 0.828 & 0.097 & 0.685 & 4.03 & 0.886 & 0.099 & 0.784 & 4.08 \\
\hline 15 & Oimpe & 4.05 & 0.905 & 0.105 & 0.819 & 3.94 & 0.891 & 0.100 & 0.794 & 3.99 \\
\hline 16 & Prestige of a job & 4.12 & 0.793 & 0.092 & 0.629 & 3.89 & 0.955 & 0.107 & 0.911 & 4.00 \\
\hline 17 & Senior / s & 4.54 & 0.666 & 0.077 & 0.444 & 4.01 & 1.037 & 0.116 & .076 & 4.27 \\
\hline 18 & Separate decision making & 4.24 & 0.808 & 0.094 & 0.652 & 3.86 & 0.978 & 0.109 & 0.956 & 4.05 \\
\hline 19 & Self-re & 4.26 & 0.861 & 0.100 & 0.741 & 4.00 & 1.055 & 0.118 & 1.114 & 4.12 \\
\hline 20 & Soci & 3.84 & 0.966 & 0.112 & 0.932 & 3.56 & 1.157 & 0.129 & 1.338 & 3.69 \\
\hline 21 & Fair evalu & 4.39 & 0.889 & 0.103 & 0.790 & 3.95 & 1.231 & 0.138 & 1.516 & 4.16 \\
\hline 22 & Workplace Safety & 4.27 & 0.816 & 0.095 & 0.666 & 3.78 & 1.273 & 0.142 & 620 & 4.01 \\
\hline 23 & Psychic load & 4.04 & 1.053 & 0.122 & 1.108 & 3.71 & 1.127 & 0.126 & 1.271 & 3.87 \\
\hline 24 & Company vision & 3.96 & 0.943 & 0.110 & 0.889 & 3.72 & 1.085 & 0.122 & 1.178 & 3.84 \\
\hline 25 & Region development & 3.70 & 1.131 & 0.132 & 1.280 & 3.30 & 1.226 & 0.137 & 1.504 & 3.49 \\
\hline 26 & Education and personal growth & 4.09 & 0.995 & 0.116 & 0.991 & 4.06 & 1.035 & 0.116 & 1.072 & 4.08 \\
\hline 27 & Ecological approach & 3.78 & 0.983 & 0.114 & 0.966 & 3.50 & 1.243 & 0.139 & 1.544 & 3.64 \\
\hline 28 & Free time & 4.05 & 0.920 & 0.107 & 0.846 & 3.95 & 1.200 & 0.134 & 1.441 & 4.00 \\
\hline 29 & Recognition & 4.11 & 0.915 & 0.106 & 0.837 & 3.88 & 1.236 & 0.138 & 1.528 & 3.99 \\
\hline 30 & Basic salary & 4.43 & 0.938 & 0.109 & 0.879 & 4.25 & 1.061 & 0.119 & 1.127 & 4.34 \\
\hline
\end{tabular}


Within the research, differences between men and women, tested by the ANOVA test at the level of significance of 5\% (Table 3), were detected. Statistically significant differences were determined within motivation factors according to genders: good colleagues, communication at workplace, prestige - names of company, feedback to work results, approach of superior, individual decision making, fair evaluation of employee and regional development.

Table 3

ANOVA test of evaluation of the importance of motivational factors by gender

\begin{tabular}{|c|c|c|c|c|c|c|}
\hline Number of motivational factor & & $\begin{array}{l}\text { Sum of } \\
\text { Squares }\end{array}$ & df & $\begin{array}{l}\text { Mean } \\
\text { Square }\end{array}$ & $\mathrm{F}$ & Sig. \\
\hline \multirow{3}{*}{1 Workplace atmosphere } & Between Groups & 3.313 & 1 & 3.313 & 3.394 & 0.067 \\
\hline & Within Groups & 148.401 & 152 & 0.976 & & \\
\hline & Total & 151.714 & 153 & & & \\
\hline \multirow{3}{*}{2 Good working team } & Between Groups & 5.583 & 1 & 5.583 & 7.264 & 0.008 \\
\hline & Within Groups & 116.814 & 152 & 0.769 & & \\
\hline & Total & 122.396 & 153 & & & \\
\hline \multirow{3}{*}{3 More financial rewards } & Between Groups & 0.550 & 1 & 0.550 & 0.515 & 0.474 \\
\hline & Within Groups & 162.288 & 152 & 1.068 & & \\
\hline & Total & 162.838 & 153 & & & \\
\hline \multirow{3}{*}{4 Physical demands of work } & Between Groups & 0.193 & 1 & 0.193 & 0.185 & 0.668 \\
\hline & Within Groups & 159.034 & 152 & 1.046 & & \\
\hline & Total & 159.227 & 153 & & & \\
\hline \multirow{3}{*}{5 Job security } & Between Groups & 0.547 & 1 & 0.547 & 0.555 & 0.457 \\
\hline & Within Groups & 149.609 & 152 & 0.984 & & \\
\hline & Total & 150.156 & 153 & & & \\
\hline \multirow{3}{*}{$\begin{array}{l}6 \text { Communication with } \\
\text { colleagues }\end{array}$} & Between Groups & 4.086 & 1 & 4.086 & 5.416 & 0.021 \\
\hline & Within Groups & 114.674 & 152 & 0.754 & & \\
\hline & Total & 118.760 & 153 & & & \\
\hline \multirow{3}{*}{7 Prestige / company name } & Between Groups & 5.464 & 1 & 5.464 & 5.186 & 0.024 \\
\hline & Within Groups & 160.146 & 152 & 1.054 & & \\
\hline & Total & 165.610 & 153 & & & \\
\hline \multirow{3}{*}{8 Applying own abilities } & Between Groups & 2.268 & 1 & 2.268 & 3.230 & 0.074 \\
\hline & Within Groups & 106.725 & 152 & 0.702 & & \\
\hline & Total & 108.994 & 153 & & & \\
\hline \multirow{3}{*}{$\begin{array}{l}9 \text { The content and type of } \\
\text { work performed }\end{array}$} & Between Groups & 1.559 & 1 & 1.559 & 2.133 & 0.146 \\
\hline & Within Groups & 111.065 & 152 & 0.731 & & \\
\hline & Total & 112.623 & 153 & & & \\
\hline \multirow{3}{*}{10 Performance feedback } & Between Groups & 2.766 & 1 & 2.766 & 3.908 & 0.050 \\
\hline & Within Groups & 107.572 & 152 & 0.708 & & \\
\hline & Total & 110.338 & 153 & & & \\
\hline \multirow{3}{*}{11 Working hours } & Between Groups & 1.627 & 1 & 1.627 & 1.643 & 0.202 \\
\hline & Within Groups & 150.509 & 152 & 0.990 & & \\
\hline & Total & 152.136 & 153 & & & \\
\hline \multirow{3}{*}{12 Working environment } & Between Groups & 2.429 & 1 & 2.429 & 3.181 & 0.077 \\
\hline & Within Groups & 116.065 & 152 & 0.764 & & \\
\hline & Total & 118.494 & 153 & & & \\
\hline \multirow{3}{*}{13 Work performance } & Between Groups & 2.534 & 1 & 2.534 & 3.772 & 0.054 \\
\hline & Within Groups & 102.122 & 152 & 0.672 & & \\
\hline & Total & 104.656 & 153 & & & \\
\hline \multirow{3}{*}{14 Career advancement } & Between Groups & 0.603 & 1 & 0.603 & 0.818 & 0.367 \\
\hline & Within Groups & 111.292 & 151 & 0.737 & & \\
\hline & Total & 111.895 & 152 & & & \\
\hline
\end{tabular}




\begin{tabular}{|c|c|c|c|c|c|c|}
\hline \multirow{3}{*}{15 Competences } & Between Groups & 0.522 & 1 & 0.522 & 0.648 & 0.422 \\
\hline & Within Groups & 122.471 & 152 & 0.806 & & \\
\hline & Total & 122.994 & 153 & & & \\
\hline \multirow{3}{*}{16 Prestige of a job } & Between Groups & 2.107 & 1 & 2.107 & 2.717 & 0.101 \\
\hline & Within Groups & 117.893 & 152 & 0.776 & & \\
\hline & Total & 120.000 & 153 & & & \\
\hline \multirow{3}{*}{17 Senior / supervisor access } & Between Groups & 10.719 & 1 & 10.719 & 13.882 & 0.000 \\
\hline & Within Groups & 117.366 & 152 & 0.772 & & \\
\hline & Total & 128.084 & 153 & & & \\
\hline \multirow{3}{*}{$\begin{array}{l}18 \text { Separate decision } \\
\text { making }\end{array}$} & Between Groups & 5.573 & 1 & 5.573 & 6.880 & 0.010 \\
\hline & Within Groups & 123.109 & 152 & 0.810 & & \\
\hline & Total & 128.682 & 153 & & & \\
\hline \multirow{3}{*}{19 Self-realization } & Between Groups & 2.534 & 1 & 2.534 & 2.710 & 0.102 \\
\hline & Within Groups & 142.122 & 152 & 0.935 & & \\
\hline & Total & 144.656 & 153 & & & \\
\hline \multirow{3}{*}{20 Social benefits } & Between Groups & 2.914 & 1 & 2.914 & 2.550 & 0.112 \\
\hline & Within Groups & 173.742 & 152 & 1.143 & & \\
\hline & Total & 176.656 & 153 & & & \\
\hline \multirow{3}{*}{21 Fair evaluation } & Between Groups & 7.506 & 1 & 7.506 & 6.430 & 0.012 \\
\hline & Within Groups & 177.435 & 152 & 1.167 & & \\
\hline & Total & 184.942 & 153 & & & \\
\hline \multirow{3}{*}{22 Workplace Safety } & Between Groups & 9.429 & 1 & 9.429 & 8.118 & 0.005 \\
\hline & Within Groups & 176.545 & 152 & 1.161 & & \\
\hline & Total & 185.974 & 153 & & & \\
\hline \multirow{3}{*}{23 Psychic load } & Between Groups & 4.137 & 1 & 4.137 & 3.469 & 0.064 \\
\hline & Within Groups & 181.266 & 152 & 1.193 & & \\
\hline & Total & 185.403 & 153 & & & \\
\hline \multirow{3}{*}{24 Company vision } & Between Groups & 2.163 & 1 & 2.163 & 2.084 & 0.151 \\
\hline & Within Groups & 156.752 & 151 & 1.038 & & \\
\hline & Total & 158.915 & 152 & & & \\
\hline \multirow{3}{*}{$\begin{array}{l}25 \text { Development of the } \\
\text { region }\end{array}$} & Between Groups & 6.234 & 1 & 6.234 & 4.464 & 0.036 \\
\hline & Within Groups & 212.259 & 152 & 1.396 & & \\
\hline & Total & 218.494 & 153 & & & \\
\hline \multirow{3}{*}{$\begin{array}{l}26 \text { Education and personal } \\
\text { growth }\end{array}$} & Between Groups & 0.040 & 1 & 0.040 & 0.038 & 0.845 \\
\hline & Within Groups & 157.025 & 152 & 1.033 & & \\
\hline & Total & 157.065 & 153 & & & \\
\hline \multirow{3}{*}{27 Ecological approach } & Between Groups & 3.096 & 1 & 3.096 & 2.444 & 0.120 \\
\hline & Within Groups & 192.541 & 152 & 1.267 & & \\
\hline & Total & 195.636 & 153 & & & \\
\hline \multirow{3}{*}{28 Free time } & Between Groups & 0.416 & 1 & 0.416 & 0.360 & 0.549 \\
\hline & Within Groups & 175.584 & 152 & 1.155 & & \\
\hline & Total & 176.000 & 153 & & & \\
\hline \multirow{3}{*}{29 Recognition } & Between Groups & 2.089 & 1 & 2.089 & 1.746 & 0.188 \\
\hline & Within Groups & 181.885 & 152 & 1.197 & & \\
\hline & Total & 183.974 & 153 & & & \\
\hline \multirow{3}{*}{ 30. Basic salary } & Between Groups & 1.279 & 1 & 1.279 & 1.270 & 0.262 \\
\hline & Within Groups & 153.162 & 152 & 1.008 & & \\
\hline & Total & 154.442 & 153 & & & \\
\hline
\end{tabular}

Note: statistically significant differences within the motivation factor are marked thick

Results of the ANOVA test demonstrated that the atmosphere at workplace has the same importance for both groups without statistically significant difference, dependent on gender. In case of women, good colleagues, approach of superior and communication at workplace were evaluated at a significantly higher level as 
in case of men. It proves the fact that for women the interpersonal relations within work procedure enjoy clearly higher importance. They consider it as more important than the system of basic financial evaluation. On the other hand, men consider the base wage as the second most important factor. From the perspective of importance, both groups see then the utilisation of their skills and the subject and type of work as important the factor, demonstrating the need of working in their profession and use of their knowledge and experiences. At the same time, it's also significantly more important for women to get feedback to their performance as well as the possibility to decide on their own, what men consider as less important. This fact may be connected to higher self-confidence in management. On the basis of results of the ANOVA test, we may state that the workers, marked as talents, show statistically significant differences in the context of preference of motivational factors according to gender. Thus, we refuse the H1 work hypothesis for the benefit of the alternative one.

For the determination of appropriate tool to select an optimal motivation program from more options, the AHP method looks as appropriate. This method seems to be appropriate for the reason that it provides the possibility of comparison of options in words on the basis of weight of determined criteria (motivation factors) by expert evaluator. In this case study, three workers of selected enterprise are in the role of expert evaluators. These are workers of human resources department and top management, proposing three options of motivation programs. Research will evaluate the possibility of use of the AHP method in this case. Following the suggestion of one of the investigated enterprises, we will apply selection from these three options of motivation programs:

- Motivation program V1: Motivation program is focused mainly on the diversification of higher amount of personal evaluation according to work performance with the determination of lower base wage. This is determined in a very specifically prepared evaluation system for fair evaluation and strong feedback to work results. It provides high possibility of education and personal growth (targeted plan of talents' education), taking the high potential of career growth into consideration. This system is based rather on competitive atmosphere and mutual rivalry, where the impact on higher performance is expected. Social benefits are also strongly diversified according to status in hierarchy and credit in enterprise. There's a strong feedback to performance in a form of evaluation interviews, held biannually. Work hours are fixed and controlled, workers have the possibility to get refreshment at workplace (juics, mineral waters, teas, coffee and sandwiches) besides lunch. Safety at workplace is solved in compliance with EU legal rules and assessed in regular intervals.

- Motivation program V2: This motivation program is focused on the setting of lower wage evaluation in comparison to competitors, while there exists a higher portion of personal evaluation, dependent on work results, fixed for a longer period of time (year). This setting should create fair evaluation of workers without strong pressure on rivalry and competition. In particular, cooperation, 
collaboration, open communication and friendly atmosphere are supported. For this purpose, informal meetings and activities, formation of project teams through hierarchy and coaching approach of managers become tradition. Coaching management style is supported also by the need of self-fulfillment, individual decision-making and utilisation of own skills of individuals. At the same time, management style supports regular bidirectional feedback between the superior and subordinated employees. Career growth is slower and based on proven abilities and education while personal growth is executed according to a targeted and individually focused plan for talent development in enterprise. Significant attention is paid to work environment - configuration of work space, offices, light, entry into building and its surrounding area. Safety at work is solved in compliance with EU legal rules and assessed in regular intervals.

- Motivation program V3: This motivation program is based on a higher portion of base wage (in comparison with competitors) without any additional evaluation portion. Fairness in evaluation is solved by feedback to performance and the possibility to get wide social benefits and by program for education, personal and career growth. Management is solved by a strong structure of hierarchy with clearly set formal competences and subject of work. The approach of superior is very formal, but subordinated employees may participate on solution and decision-making process of departments. For the purpose of collective integration, mutual meetings are created in a form of corporate breakfasts and sport activities. Subordinated employees get maximum feedback over year, always on quarterly basis in a form of assessment interview, where they can provide comments. Safety at work is solved in compliance with EU legal rules and assessed in regular intervals.

With regard to the scope of this article, ten most important criteria (motivation factors) are considered for the selection of appropriate option of motivation program within a group of women and men. Table 4 shows the calculation of importance weights of ten most preferred criteria within motivation of women and men. This calculation is based on the recalculation of final values of arithmetic mean value, gained by the evaluation at Likert scale from talents in the transportation and logistics industry.

Table 4

Weights of criteria for men and women - the most important motivational factors

\begin{tabular}{|c|c|c|c|c|c|c|}
\hline \multirow[b]{2}{*}{ code } & \multicolumn{3}{|c|}{ Women' weight of criteria } & \multicolumn{3}{|c|}{ Men weight of criteria } \\
\hline & \multicolumn{2}{|r|}{ criterion } & \multirow{2}{*}{\begin{tabular}{|r|} 
weight \\
0.103134
\end{tabular}} & \multicolumn{2}{|r|}{ criterion } & \multirow{2}{*}{\begin{tabular}{|c|} 
weight \\
0.103127 \\
\end{tabular}} \\
\hline $\mathrm{K} 1$ & 1 & Workplace atmosphere & & 1 & Workplace atmosphere & \\
\hline $\mathrm{K} 2$ & 2 & Good working team & 0.103134 & 30 & Basic salary & 0.102225 \\
\hline $\mathrm{K} 3$ & 17 & Senior / supervisor access & 0.102221 & 2 & Good working team & 0.101022 \\
\hline $\mathrm{K} 4$ & 6 & Communication with colleagues & 0.101612 & 6 & Communication with colleagues & 0.100722 \\
\hline $\mathrm{K} 5$ & 30 & Basic salary & 0.099787 & 8 & Applying own abilities & 0.100120 \\
\hline K6 & 8 & Applying own abilities & 0.099179 & 9 & Content and type of work & 0.099820 \\
\hline $\mathrm{K} 7$ & 21 & Fair financial remuneration & 0.098874 & 5 & Job security & 0.099519 \\
\hline $\mathrm{K} 8$ & 9 & Content and type of work & 0.097962 & 12 & Working environment & 0.098617 \\
\hline
\end{tabular}


\begin{tabular}{l|l|l} 
K9 & 12 & Working environment
\end{tabular}

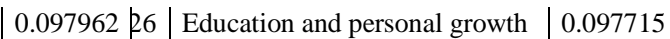
\begin{tabular}{l|l|l}
\hline K10 & 22 & Workplace safety \\
\hline
\end{tabular}

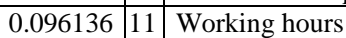
Total 1.000000 Total 0.097114 1.000000

Table 5

Saaty's matrix for variants of motivational programs according to criteria for women

\begin{tabular}{|c|c|c|c|c|c|c|c|c|c|c|c|}
\hline K1 & V1 & V2 & V3 & $\overline{v_{i}^{\prime}}$ & $\overline{v_{i}}$ & K6 & V1 & V2 & V3 & $\overline{\mathbf{v}_{\mathbf{i}}^{\prime}}$ & $\overline{v_{i}}$ \\
\hline V1 & 1 & 0.12 & 0.21 & 0.29516 & 0.06552 & V1 & 1 & 0,27 & 1,00 & 0,64850 & 0,15194 \\
\hline $\mathrm{V} 2$ & 8.33 & 1 & 3.67 & 3.12630 & 0.69394 & V2 & 3,67 & 1 & 8,33 & 3,12630 & 0,73249 \\
\hline V3 & 4.67 & 0.27 & 1 & 1.08371 & 0.24055 & V3 & 1,00 & 0,12 & 1 & 0,49324 & 0,11557 \\
\hline $\mathrm{K} 2$ & V1 & V2 & V3 & $\overline{v_{i}^{\prime}}$ & $\overline{v_{i}}$ & K7 & V1 & $\mathrm{V2}$ & V3 & $\overline{v_{i}^{\prime}}$ & $\overline{\mathbf{v}_{\mathbf{i}}}$ \\
\hline V1 & 1 & 0.14 & 0.19 & 0.29460 & 0.06747 & V1 & 1 & 0.33 & 1.33 & 0.76314 & 0.21972 \\
\hline V2 & 7.33 & 1 & 3.33 & 2.90220 & 0.66467 & V2 & 3.00 & 1 & 3.00 & 2.08008 & 0.59890 \\
\hline V3 & 5.33 & 0.30 & 1 & 1.16961 & 0.26787 & V3 & 0.75 & 0.33 & 1 & 0.62996 & 0.18138 \\
\hline K3 & V1 & $\mathrm{V2}$ & V3 & $\overline{v_{i}^{\prime}}$ & $\overline{\mathbf{v}_{\mathbf{i}}}$ & K8 & V1 & $\mathrm{V} 2$ & V3 & $\overrightarrow{\mathbf{v}_{\mathbf{i}}^{\prime}}$ & $\overline{\mathbf{v}_{\mathbf{i}}}$ \\
\hline V1 & 1 & 0.12 & 0.23 & 0.30254 & 0.06744 & V1 & 1 & 0.43 & 0.96 & 0.74286 & 0.21555 \\
\hline $\mathrm{V} 2$ & 8.33 & 1 & 3.67 & 3.12630 & 0.69688 & V2 & 2.33 & 1 & 3.67 & 2.04526 & 0.59347 \\
\hline V3 & 4.33 & 0.27 & 1 & 1.05726 & 0.23568 & V3 & 1.05 & 0.27 & 1 & 0.65818 & 0.19098 \\
\hline K4 & V1 & V2 & V3 & $\mathbf{v}_{\mathbf{i}}$ & $\mathbf{v}_{\mathbf{i}}$ & K9 & V1 & $\mathrm{V} 2$ & V3 & $\mathbf{v}_{\mathbf{i}}$ & $\mathbf{v}_{\mathbf{i}}$ \\
\hline V1 & 1 & 0.12 & 0.19 & 0.28231 & 0.06216 & $\mathrm{V1}$ & 1 & 0.43 & 0.43 & 0.56844 & 0.17082 \\
\hline $\mathrm{V2}$ & 8.33 & 1 & 3.67 & 3.12630 & 0.68836 & $\mathrm{~V} 2$ & 2.33 & 1 & 2.33 & \begin{tabular}{|l|}
1.75921 \\
\end{tabular} & 0.52866 \\
\hline V3 & 5.33 & 0.27 & 1 & 1.13303 & 0.24948 & V3 & 2.33 & 0.43 & 1 & 1.00000 & 0.30051 \\
\hline K5 & V1 & V2 & V3 & $\overrightarrow{v_{i}^{\prime}}$ & $\overline{v_{i}}$ & K10 & V1 & $\mathrm{V} 2$ & V3 & $\overrightarrow{\mathbf{v}_{\mathbf{i}}^{\prime}}$ & $\overline{v_{i}}$ \\
\hline V1 & 1 & 1.00 & 0.13 & 0.50000 & 0.10000 & V1 & 1 & 1.00 & 1.00 & 1.00000 & 0.33333 \\
\hline $\mathrm{V} 2$ & 1.00 & 1 & 0.13 & 0.50000 & 0.10000 & $\mathbf{V 2}$ & 1.00 & 1 & 1.00 & 1.00000 & 0.33333 \\
\hline V3 & 8.00 & 8.00 & 1 & 4.00000 & 0.80000 & V3 & 1.00 & 1.00 & 1 & 1.00000 & 0.33333 \\
\hline
\end{tabular}

Table 6

Saaty's matrix for variants of motivational programs according to criteria for men

\begin{tabular}{|c|c|c|c|c|c|c|c|c|c|c|c|}
\hline K1 & V1 & $\mathrm{V} 2$ & V3 & $\mathbf{v}_{\mathrm{i}}^{\prime}$ & $\mathbf{v}_{\mathbf{i}}$ & K6 & V1 & V2 & V3 & $\mathbf{v}_{\mathbf{i}}^{\prime}$ & $\mathbf{v}_{\mathbf{i}}$ \\
\hline V1 & 1 & 0.12 & 0.21 & 0.29516 & 0.06552 & V1 & 1 & 0.30 & 1.67 & 0.79370 & 0.21780 \\
\hline $\mathrm{V} 2$ & 8.33 & 1 & 3.67 & 3.12630 & 0.69394 & V2 & 3.33 & 1 & 3.67 & 2.30347 & 0.63210 \\
\hline V3 & 4.67 & 0.27 & 1 & 1.08371 & 0.24055 & V3 & 0.60 & 0.27 & 1 & 0.54697 & 0.15009 \\
\hline $\mathrm{K} 2$ & V1 & V2 & V3 & $\overline{v_{i}^{\prime}}$ & $\overline{v_{i}}$ & K7 & V1 & $\mathrm{V2}$ & V3 & $\overrightarrow{\mathbf{v}_{\mathbf{i}}^{\prime}}$ & $\overline{v_{i}}$ \\
\hline V1 & 1 & 1.00 & 0.13 & 0.50000 & 0.10000 & V1 & 1 & 1.00 & 1.00 & 1.00000 & 0.33333 \\
\hline $\mathrm{V} 2$ & 1.00 & 1 & 0.13 & 0.50000 & 0.10000 & V2 & 1.00 & 1 & 1.00 & 1.00000 & 0.33333 \\
\hline V3 & 8.00 & 8.00 & 1 & 4.00000 & 0.80000 & V3 & 1.00 & 1.00 & 1 & 1.00000 & 0.33333 \\
\hline K3 & V1 & $\mathrm{V2}$ & V3 & $\mathbf{v}_{\mathbf{i}}$ & $\mathbf{v}_{\mathbf{i}}$ & K8 & V1 & $\mathrm{V2}$ & V3 & $\mathbf{v}_{\mathbf{i}}$ & $\mathbf{v}_{\mathbf{i}}$ \\
\hline V1 & 1 & 0.14 & 0.19 & 0.29460 & 0.06747 & V1 & 1 & 0.43 & 0.43 & 0.56844 & 0.17082 \\
\hline $\mathrm{V} 2$ & 7.33 & 1 & 3.33 & 2.90220 & 0.66467 & V2 & 2.33 & 1 & 2.33 & 1.75921 & 0.52866 \\
\hline $\mathbf{V 3}$ & 5.33 & 0.30 & 1 & 1.16961 & 0.26787 & $\mathrm{V3}$ & 2.33 & 0.43 & 1 & 1.00000 & 0.30051 \\
\hline K4 & V1 & V2 & V3 & $\mathbf{v}_{\mathbf{i}}^{\prime}$ & $\mathbf{v}_{\mathbf{i}}$ & K9 & V1 & $\mathrm{V} 2$ & V3 & $\mathbf{v}_{\mathbf{i}}^{\prime}$ & $\mathbf{v}_{\mathbf{i}}$ \\
\hline V1 & 1 & 0.12 & 0.19 & 0.28231 & 0.06216 & V1 & 1 & 0.43 & 2.33 & 1.00000 & 0.28686 \\
\hline $\mathrm{V} 2$ & 8.33 & 1 & 3.67 & 3.12630 & 0.68836 & $\mathrm{~V} 2$ & 2.33 & 1 & 3.33 & 1.98131 & 0.56836 \\
\hline V3 & 5.33 & 0.27 & 1 & 1.13303 & 0.24948 & $\mathrm{V3}$ & 0.43 & 0.30 & 1 & 0.50472 & 0.14478 \\
\hline K5 & V1 & $\mathrm{V} 2$ & V3 & $\mathbf{v i}^{\prime}$ & $\mathbf{v}_{\mathbf{i}}$ & K10 & V1 & V2 & $\mathbf{V 3}$ & $\mathbf{v}_{\mathbf{i}}^{\prime}$ & $\mathbf{v}_{\mathbf{i}}$ \\
\hline V1 & 1 & 0.27 & 1.00 & 0.64850 & 0.15194 & V1 & 1 & 4.00 & 8.00 & 3.17480 & 0.71335 \\
\hline $\mathrm{V} 2$ & 3.67 & 1 & 8.33 & 3.12630 & 0.73249 & $\mathrm{V2}$ & 0.25 & 1 & 3.33 & 0.94104 & 0.21144 \\
\hline $\mathrm{V3}$ & 1.00 & 0.12 & 1 & 0.49324 & 0.11557 & V3 & 0.13 & 0.30 & 1 & 0.33472 & 0.07521 \\
\hline
\end{tabular}


Comparison of options appropriateness in pairs for women and men according to respective criteria is presented in the Table 5 and Table 6 . In this comparison, values from 1 to 9 are assigned to expert evaluators (in our case, 3 evaluators from selected enterprise) within evaluation in words, where 1 means that options are equally appropriate and 9 means that the first option is absolutely more appropriate than the second one. In the event of opposite ratio, a converse value of this expression is used, like 1/9. The condition of matrix consistency through the value $\lambda \max$ is necessary, being equal to the number of compared " $\mathrm{k}$ " elements under full consistency of matrix. The evaluation of adequate level of consistency is solved by the C.I. (consistency index), reaching the values up to 0.1 for a sufficiently consistent matrix. Results of the consistency index within the matrix for women and men reach values within the range from 0.0046 to 0.0465 their value does not exceed the limit of 0.1 , and therefore, we may consider the results of matrixes as interpretable.

Table 7

Evaluation of the suitability of variants using AHP method for women

\begin{tabular}{|c|c|c|c|c|c|c|c|}
\hline \multirow{2}{*}{$\dot{\vec{z}}$} & \multicolumn{3}{|c|}{$\begin{array}{l}\text { The weight of the variants of } \\
\text { motivational program }\end{array}$} & \multirow{2}{*}{ 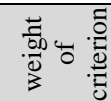 } & \multicolumn{3}{|c|}{ Evaluation results of the programs } \\
\hline & V1 & \begin{tabular}{|l|} 
V2 \\
\end{tabular} & V3 & & V1 & V2 & V3 \\
\hline K1 & 0.06552 & 0.69394 & 0.24055 & 0.10313 & 0.00676 & 0.07157 & 0.02481 \\
\hline $\mathbf{K 2}$ & 0.06747 & 0.66467 & 0.26787 & 0.10313 & 0.00696 & 0.06855 & 0.02763 \\
\hline K3 & 0.06744 & 0.69688 & 0.23568 & 0.10222 & 0.00689 & 0.07124 & 0.02409 \\
\hline K4 & 0.06216 & 0.68836 & 0.24948 & 0.10161 & 0.00632 & 0.06995 & 0.02535 \\
\hline K5 & 0.10000 & 0.10000 & 0.80000 & 0.09979 & 0.00998 & 0.00998 & 0.07983 \\
\hline K6 & 0.15194 & 0.73249 & 0.11557 & 0.09918 & 0.01507 & 0.07265 & 0.01146 \\
\hline K7 & 0.21972 & 0.59890 & 0.18138 & 0.09887 & 0.02173 & 0.05922 & 0.01793 \\
\hline K8 & 0.21780 & 0.63210 & 0.15009 & 0.09796 & 0.02134 & 0.06192 & 0.01470 \\
\hline K9 & 0.17082 & 0.52866 & 0.30051 & 0.09796 & 0.01673 & 0.05179 & 0.02944 \\
\hline K10 & 0.33333 & 0.33333 & 0.33333 & 0.09614 & 0.03205 & 0.03205 & 0.03205 \\
\hline \multicolumn{5}{|c|}{ Total evaluation } & 0.14381 & 0.56890 & 0.28729 \\
\hline \multicolumn{5}{|c|}{ The order of suitability of the variants } & 3 & 1 & 2 \\
\hline
\end{tabular}

Table 7

Evaluation of the suitability of variants using AHP method for men

\begin{tabular}{|c|c|c|c|c|c|c|c|}
\hline \multirow[t]{2}{*}{ نُّ } & \multicolumn{3}{|c|}{$\begin{array}{c}\text { The weight of the variants of } \\
\text { motivational program }\end{array}$} & \multirow{2}{*}{ 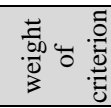 } & \multicolumn{3}{|c|}{ Evaluation results of the programs } \\
\hline & V1 & $\mathrm{V} 2$ & V3 & & V1 & V2 & V3 \\
\hline K1 & 0.06552 & 0.69394 & 0.24055 & 0.10313 & 0.00676 & 0.07156 & 0.02481 \\
\hline K2 & 0.10000 & 0.10000 & 0.80000 & 0.10222 & 0.01022 & 0.01022 & 0.08178 \\
\hline K3 & 0.06747 & 0.66467 & 0.26787 & 0.10102 & 0.00682 & 0.06715 & 0.02706 \\
\hline K4 & 0.06216 & 0.68836 & 0.24948 & 0.10072 & 0.00626 & 0.06933 & 0.02513 \\
\hline K5 & 0.15194 & 0.73249 & 0.11557 & 0.10012 & 0.01521 & 0.07334 & 0.01157 \\
\hline K6 & 0.21780 & 0.63210 & 0.15009 & 0.09982 & 0.02174 & 0.06310 & 0.01498 \\
\hline K7 & 0.33333 & 0.33333 & 0.33333 & 0.09952 & 0.03317 & 0.03317 & 0.03317 \\
\hline K8 & 0.17082 & 0.52866 & 0.30051 & 0.09862 & 0.01685 & 0.05214 & 0.02964 \\
\hline K9 & 0.28686 & 0.56836 & 0.14478 & 0.09771 & 0.02803 & 0.05554 & 0.01415 \\
\hline K10 & 0.71335 & 0.21144 & 0.07521 & 0.09711 & 0.06928 & 0.02053 & 0.00730 \\
\hline \multicolumn{5}{|c|}{ Total evaluation } & 0.21433 & 0.51608 & 0.26959 \\
\hline \multicolumn{5}{|c|}{ The order of suitability of the variants } & 3 & 1 & 2 \\
\hline
\end{tabular}


The result of Saaty's matrix are the weights of respective options for each assessed criterium (Tables 7 and 8). These weights of options under criteria are recalculated through the weights of criteria in the Table 7 and the sum of resulting values within respective options determines the order of their appropriateness. For women, the V2 option seems to be the most appropriate, while subsequently the V3 option, with a lower preference by $49.5 \%$, is identified. In case of men (Table $8)$, the V2 option seems to be the most appropriate, while subsequently, the V3 option is preferred, losing by $47.8 \%$ compared to the previous one.

From the stated application of the AHP method to this specific case it's clear that for both groups of leading workers (marked as talents by enterprises), working in the transportation and logistics industry, the second option of motivation program, proposed by selected enterprise, is the most optimal one. An interesting aspects is the fact that despite the preference of base wage by men at the second top place, the second option is more appropriate, having its base wage at lower level in comparison with competitors while the total evaluation is based on another financial aspect of personal evaluation of performance for certain period of time. From the stated above it's clear that the option based on cooperation atmosphere, open communication and coaching approach by superiors, it forms appropriate motivation conditions for workers of both gender categories, despite a lower level of base wage. Also, the workers at managing positions in the transportation and logistics industry, considered as talents, have such wage remuneration that this hygienic factor is fulfilled and the relationship motivation factors are becoming more motivational. From the result of the use of the AHP method, we can confute the $\mathrm{H} 2$ work hypothesis for the benefit of the alternative one. For the group of workers in consideration, the most appropriate motivation program is the option that does not offer the highest level of base wage.

Vlacseková and Mura [44] [45] stress the fact that motivation is very individual and managers have a difficult role to motivate their employees. Research has confirmed a stronger level of motivation by internal factors more than external factors, which superiors should not overlook. Based on our results, it can be stated that women tend to assign greater importance to all factors in general compared to men. In the context of comparable research, this trend is also seen in women [46] [47] [48], regardless of nationality [49] [50] [51]. Hitka et al. [52] presents the results of research of motivational preferences of managers in woodworking companies in Slovakia. He determined 3 basic clusters, which differ in the preferences of motivational factors. Two clusters consider the basic salary to be the most important motivational factor and the third cluster to be primarily a fair evaluation system. The results of this research may differ for a number of reasons from ours, as respondents live under different national economic conditions, but it is also a different professional field of work and 2016, and the fact that they are not labeled as talents. On the contrary, a more recent study from 2019 by Lorincova at al. [53] about the motivational preferences for the senior management category correspond to our findings from the gender perspective. 
Slovak senior management prefers the basic salary factor to a workplace atmosphere factor for both men and women. While for women, the second most important factor is a good work team and then a basic salary. Men have a sequence of two other factors opposite. Mikkelsen et al. [54] states that employee motivation requirements may change even if their regional needs are met. In view of this, it is advisable to continuously review the effectiveness of the current incentive program and to diversify it as needed. Greiner [55] draws attention to the fact that, for each enterprise, the incentive system is a complex and costly activity, but according to Kachaňáková and Urbancová [56], its effectiveness can significantly affect and promote the competitiveness of the company. Vetráková [5] [57] adds that the effectiveness of the motivation program is influenced by a precise analysis of employees and not neglecting this aspect can significantly strengthen the incentive program.

\section{Conclusions}

The aim of the paper is to identify the motivation preferences of Czech managers on critical management positions of transport and logistics companies and to determine the method for effective setting of motivational factors in order to keep them in the company. Correct definition and selection of a motivational program may depend on multiple factors. In this article, attention is focused on workers referred to as talents who work in the transport and logistics field. The most important thing for these workers is the atmosphere in the workplace and then the preferences diversify by gender. For men, the amount of basic salary is another powerful incentive. However, in general it can be said that, in the first place, relationship motivation factors such as workplace atmosphere, good workforce and workplace communication are at the forefront. This may be due to the fact that these workers have a relatively high financial reward and a clear career in the company. For this reason, the importance of financial valuation and career advancement is shifted to other aspects. This also explains the appropriateness of a determined motivational program for both gender groups. However, it is a matter of further research, as the motivation of the category of workers under investigation will evolve over time and also the impact of satisfying other motivational factors on the perception of their importance. Conclusions in this article may be helpful for the entrepreneurs not only in the area of transportation and logistics services to get a strong system for the purpose of keeping talents in the enterprise, but also for the formation of satisfaction and loyalty towards enterprise. Presented method of setup of motivation factors is universally utilizable for any industry and region.

\section{Acknowledgement}

This work was supported by TL02000559 Safe and secure cities for pedestrians and senior citizens, TL02000017 Inter-generational management to support digitization in construction, TL01000349 Stabilization and development of SMEs in rural areas, SVV202002 Trends in human resource management in transport 
and logistics companies and $\mathrm{KH} 061712$ Financial and social aspects in establishing a regional transport enterprise.

\section{References}

[1] A. Kucharčíková, M. Mičiak, and M. Hitka: Evaluating the effectiveness of investment in human capital in e-business enterprise in the context of sustainability. Sustainability, 10(9), 2018, 3211

[2] E. Zaborova, T. Markova: Human capital as a factor of regional development. 12 ${ }^{\text {th }}$ International Days of Statistics and Economics, 2018

[3] R. Kampf, S. Lorincová, M. Hitka, and O. Stopka: Generational differences in the perception of corporate culture in European transport enterprises. Sustainability, 9(9), 2017, 1561

[4] S. Lorincová: Human resource and corporate culture: Gender-based differences in the assessment. Central European Journal of Labour Law and Personnel Management, 1(1), 2018, pp. 28-45

[5] M. Vetráková, and L. Mazúchová: Draft of management model of work motivation in hotels. Procedia-Social and Behavioral Sciences, 230, 2016, 422-429

[6] M. Žambochová, and K. Tišlerová: Potential of Indirect Financing of Higher Education Institutions in Terms of Global Economic Development. Liberec Economic Forum, 2011, pp. 604

[7] I. Kmecova: Analysis of the efficiency of the educational processes of the subjects business management, human resource management, and mathematics, and their comparison. INTED, 2018, pp. 1781-1788

[8] M. Hitka, and P. Lejsková: Increasing efficiency of enterprise management employees' careers. VŠTE v ČB, 2015

[9] A. Šatanová, J. Závadský, M. Sedliačiková, M. Potkány, Z. Závadská, and M. Holíková: How Slovak small and medium manufacturing enterprises maintain quality costs: an empirical study and proposal for a suitable model. Total quality management \& business excellence, 26(11-12), 2015, $1146-1160$

[10] Z. Stacho, K. Stachová, and J. Papula: The changes in the focus of Slovak organisations on talent management. Business. Theory and Practice, 19, 2018,255

[11] P. Seemann, and V. Farkasova: Coaching As A Tool For Improving The Quality Of Managerial Work. 15 ${ }^{\text {th }}$ International Scientific Conference on Globalization and its Socio-Economic Consequences, 2015, pp. 661-669

[12] E. Farndale, H. Scullion, and P. Sparrow: The role of the corporate HR function in global talent management. Journal of world business, 45(2), 2010, pp. 161-168 
[13] F. Anyim Chukwudi, J. G.Olusoji, S. Aremu Nuha: The effect of talent management on employee retention: evidence from emzor pharmaceutical industry, Lagos, Nigeria. Acta Oeconomica Universitatis Selye, 7(2), 2018, pp. $7-18$

[14] T. N. Krishnan, and H. Scullion: Talent management and dynamic view of talent in small and medium enterprises, Human Resource Management Review, 27(3), 2016, pp. 431-441

[15] K. Stachová, J. Papula, Z. Stacho, and L. Kohnová: External partnerships in employee education and development as the key to facing industry 4.0 challenges. Sustainability, 11(2), 2019, 345

[16] J. Žul'ová, M. Švec, and A. Madleňák: Personality aspects of the employee and their exploration from the GDPR perspective. Central European Journal of Labour Law and Personnel Management, 1(1), 2018, pp. 68-77

[17] J. Hudáková, M. Fil'a, and M. Maroš: 2017. Innovation potential of the regions in the Slovak republic. Acta Oeconomica Universitatis Selye 6(2), pp. $81-88$

[18] M. Dobrodolac, D. Lazarević, L. Švadlenka, and M. Živanović: A study on the competitive strategy of the universal postal service provider. Technology Analysis \& Strategic Management, 28(8), 2016, pp. 935-949

[19] N. Glišović, M. Milenković, N. Bojović, L. Švadlenka, and Z. Avramović: A hybrid model for forecasting the volume of passenger flows on Serbian railways. Operational Research, 16(2), 2016, pp. 271-285

[20] B. Dočkalová: Design as an innovative tool for developing Industry 4.0 strategies in the Czech Republic, 2019

[21] Federal Ministry of Education and Research - BMBF. Microsystems Technology - BMBF [online] [Accessed 27 Mar. 2019], 2019, Available at: https://www.bmbf.de/en/microsystems-technology-2445.html

[22] Osteu: The Impacts Of Digitizing The Labor Market. [online] [Accessed 20 Mar. 2019] 2015, Available at: https://www.vlada.cz/assets/evropskezalezitosti/analyzy-EU/Dopadydigitalizace-na-trh-prace-CR-a-EU.pdf

[23] A. Pilková, J. Volná, J. Papula, and M. Holienka: The influence of intellectual capital on firm performance among Slovak SMEs. $10^{\text {th }}$ International Conference on Intellectual Capital, Knowledge Management and Organisational Learning, 2013, pp. 329-338

[24] A. Kucharčíková, and M. Mičiak: Human capital management in transport enterprises with the acceptance of sustainable development in the Slovak Republic. Sustainability, 10(7), 2018, 2530

[25] A. Kucharčíková, and M. Mičiak: The Application of Human Capital Efficiency Management towards the Increase of Performance and 
Competitiveness in an Enterprise Operating in the Field of Distribution Logistics. NAŠE MORE, 65(4 Special issue), 2018, 276-283

[26] V. Mařík: Průmysl 4.0: challenge for the Czech Republic. Praha: Management Press, 2016

[27] S. Jigjiddorj, T. Tsogbadrakh, E. Choijil, and A. Zanabazar: The Mediating Effect of Employee Loyalty on the Relationship between Job Satisfaction and Organizational Performance. International Conference on Economics, Management and Technology in Enterprises, 2019

[28] A. Grenčíková, J. Španková, and R. Karbach: Current trends in enterprise employment policies in Slovak Republic. Actual Problems of Economics, 170(8), 2015, pp. 293-301

[29] J. Vydrová: Identification of key employee benefits relating to employee satisfaction in selected health organizations in the Czech republic. Acta Oeconomica Universitatis Selye 7 (2), 2018, pp. 175-187

[30] M. Rebet'ák, and V. Farkašová: Managing High-Potential Employees. Procedia Economics and Finance, 2015 (23), 2015, pp. 867-871

[31] D. M. Lambert, S. J. García-Dastugue, and K. L. Croxton: The role of logistics managers in the cross-functional implementation of supply chain management. Journal of business logistics, 29(1), 2008, pp. 113-132

[32] N. Batarlienè, K. Čižiūnienè, K. Vaičiūtè, L. Šapalaitè, and A. Jarašūnienè: The impact of human resource management on the competitiveness of transport companies. procedia Engineering, 187, 2017, pp. 110-116

[33] M. Hitka, S. Lorincová, M. Gejdoš, K. Klarić, and D. Weberová: Management Approach to Motivation of White-collar Employees in Forest Enterprises. BioResources, 14(3), 2019, pp. 5488-5505

[34] M. B. Myers, D. A. Griffith, P. J. Daugherty, and R. F. Lusch: Maximizing the human capital equation in logistics: education, experience, and skills. Journal of Business Logistics, 25(1), 2004, pp. 211-232

[35] G. Hofstede: National cultural dimensions, 2010

[36] S. E. Sullivan: The changing nature of careers: A review and research agenda. Journal of management, 25(3), 1999, pp. 457-484

[37] C. Hakim: Key issues in women's work: Female diversity and the polarisation of women's employment. Routledge-Cavendish. 2016

[38] J. Jablonský: Operations research, quantitative models of economic. Praha: Professional Publishing. 2002

[39] Ž. Stević, S. Vesković, M. Vasiljević, and G. Tepić: The selection of the logistics center location using AHP method. LOGIC, 2015, pp. 86-91 
[40] J. Rezaei: Best-worst multi-criteria decision-making method. Omega, 53, 2015, pp. 49-57

[41] T. L. Saaty, and R. Islam: Hierarchon vol 2: A dictionary of AHP hierarchies. RWS Publications. 2015

[42] J. Aguarón, M. T. Escobar, and J. M. Moreno-Jiménez: The precise consistency consensus matrix in a local AHP-group decision making context. Annals of Operations Research, 245(1-2), 2016, pp. 245-259

[43] J. Ližbetin, R. Kampf, K. Jeřábek, and Z. Caha: Practical Application of the Comparative Analysis of Direct Road Freight Transport and Combined Transport. Transport Means, 2016, pp. 1083-1087

[44] D. Vlacsekova, and L. Mura: Effect of motivational tools on employee satisfaction in small and medium enterprises. Oeconomia Copernicana, 8(1), 2017, pp. 111-130

[45] L. Mura, D. Vlacseková:Motivation of public employees: case study of Slovak teaching and professional staff. Administratie si Management Public, (31), 2018, pp. 67-80

[46] M. Hitka, M. Vetráková, and Z. Balázová: Differences in Motivation between Male and Female in Slovakia in 2015. Modern Applied Science, 10(1), 2016, pp. 52

[47] L. Ližbetinová, M. Hitka, and R. Kampf: Employee motivation in terms of selected attributes in the environment of Czech and Slovak transport and logistics companies. VŠTE České Budějovice, 2017

[48] S. Lorincová, P. Štarchoň, D. Weberová, M. Hitka, and M. Lipoldová: Employee Motivation as a Tool to Achieve Sustainability of Business Processes. Sustainability, 11(13), 2019, 3509

[49] L. Ližbetinová, H. Hitka, E. Zaborova, and D. Weberová: Motivational Preferences of the Czech and Russian Blue-Collar Workers. Innovation Management and Education Excellence Through Vision 2020, I-XI, 2018

[50] L. Ližbetinová, H. Hitka, C. Li, and Z. Caha: Motivation of Employees of Transport and Logistics Companies in the Czech Republic and in a Selected Region of the PRC. In MATEC Web of Conferences, 134, 2017, p. 00032

[51] M. Hitka, Z. Balazova: Comparison of Motivation Level of Service Sector Employees in The Regions of Slovakia and Austria. $2^{\text {nd }}$ Global Conference on Business, Economics, Management and Tourism, 23, 2015, pp. 348-355

[52] S. Lorincová, M. Hitka, M. Čambál, P. Szabó, J. Javorčíková: Motivation Factors Influencing Senior Managers in the Forestry and Wood-Processing Sector in Slovakia. BioResources, 11(4), 2016, pp. 10339-10348

[53] M. F. Mikkelsen, C. B. Jacobsen, and L. B. Andersen: Managing employee motivation: Exploring the connections between managers' enforcement 
actions, employee perceptions, and employee intrinsic motivation. International Public Management Journal, 20(2), 2017, pp. 183-205

[54] L. Mura, B. Gontkovicova, E. Dulova Spisakova, and Z. Hajduova: Position of Employee Benefits in Remuneration Structure. Transformations in Business \& Economics, 18, 2 (47), 2019, pp. 156-173

[55] J. M. Greiner: Motivational Programs and Productivity Improvement in Times of Limited Resources. Public Sector Performance, 2018, pp. 175-196

[56] A. Kachanakova, and H. Urbancova: Practical application of selected theoretical knowledge in human resources management. Економічний часопис-XXI, 1-2(1), 2015, pp. 48-51

[57] J. Kubal'a, M. Vetráková: Reasons of the employees' stabilization in hotels in Slovakia. Acta Oeconomica Universitatis Selye, 6(2), 2018, pp. 90-100 